\title{
The Remarkably Good Health of the Self-Employed
}

La singulière bonne santé des indépendants

\section{Élisabeth Algava, Catherine Cavalin and Sylvie Célérier}

\section{(2) OpenEdition}

\section{Journals}

\section{Electronic version}

URL: http://journals.openedition.org/travailemploi/6296

DOI: 10.4000/travailemploi.6296

ISSN: 1775-416X

\section{Publisher}

DARES - Ministère du Travail

\section{Printed version}

Date of publication: 15 December 2013

Number of pages: $55-70$

ISSN: 0224-4365

\section{Electronic reference}

Élisabeth Algava, Catherine Cavalin and Sylvie Célérier, «The Remarkably Good Health of the Self-

Employed », Travail et Emploi [Online], Hors-série | 2013, Online since 01 January 2014, connection on 20 April 2019. URL : http://journals.openedition.org/travailemploi/6296 ; DOI : 10.4000/

travailemploi.6296 


\title{
The Remarkably Good Health of the Self-Employed")
}

\author{
Élisabeth Algavaa $\left.{ }^{(* *}\right)$ Catherine Cavalin ${ }^{(* *)}$, Sylvie Célérier ${ }^{(* * *)}$
}

\begin{abstract}
The category of "self-employed" workers covers situations which are quite heterogeneous. The only thing these workers seem to have in common is a similar pattern of working time characterized by extensive working hours, flexitime, and a relative decisional autonomy. This article follows another common feature, their health status, which the self-employed declare to be better than that of salaried employees, even though on average the self-employed are a little older. This hypothesis is tested and validated from several angles in particular by excluding the influence of socio-professional categories which underlie the differences in employment status. The article also compares the consequences of illness on professional activity in the different professional situations considered. The results both confirm the relatively better health of the self-employed as well as suggest a unique mode of articulation between health and work, justifying the continuation of studies on the health of this particular group so as to better understand its characteristics and to complement our knowledge of the general mechanisms by which health and work constantly reflect on each other.
\end{abstract}

Researchers' interest in the category of selfemployed workers has recently been reactivated by the creation of a new auto-entrepreneur status. ${ }^{(1)}$ The success of the latter has furthered critical reflections on the proposed solutions to unemployment and the deregulation this may entail. The new status is suspected of transferring the risks of productive activity to the individual without the latter gaining any particular advantages. (2) Apart from this recent interest, the situation of independents has rarely been studied. It is true that the boundaries of this group present sensitive questions reported on by the authors from the very first lines of their texts. They group together a variety of professional situations which are at the same time very typical and yet quite distinct from each other, whether in the nature of the activity; the socio-professional categories involved; the status of employer or self-employed individual; (3) the type and amount of income; or the system

(*) Article published in French in Travail et emploi, $\mathrm{n}^{\circ}$ 132, octobre-décembre 2012.

(**) Ministère du Travail, de l'Emploi, de la Formation professionnelle et du Dialogue social, Direction de l'animation de la recherche, des études et des statistiques (Dares); elisabeth. algava@travail.gouv.fr

(***) Centre d'études européennes de Sciences Po, Centre d'études de l'emploi; catherine.cavalin@sciencespo.fr

(****) Centre d'études de l'emploi, Centre Pierre Naville-Université d'Évry-Val-d'Essonne; sylvie.celerier@ceerecherche.fr

(1) Loi du 4 août 2008 de modernisation de l'économie, $\mathrm{n}^{\circ}$ 2008-776, JO, 5 August 2008, p. 1271.

(2) See for example: Levratto, Serverin (2009); Domens, PIGNIER (2012).

(3) In $2005,51 \%$ were self-employed working alone, $40 \%$ were employers and 9\% were unpaid family workers (ALGAVA, VINCK, 2009). of social insurance utilized. In addition, statistical studies have to deal with populations whose size is often inadequate in conducting detailed analyses. The legal status of self-employed does not designate a stabilized employment or work reality. It calls for extreme caution when it comes to looking for features which might be common to all its components.

Yet the literature recognizes one common feature of the self-employed, one which it merely notes rather than studies. This concerns their working time, considered from the point of view of the temporal organization of their professional activities, and the control over it which they claim to have. We propose in this article to argue the case of another common characteristic, this time concerning their health status, particularly their better health relative to that of salaried workers. This seemingly more favourable situation for the self-employed has already been noted in the literature and in part discussed. ${ }^{(4)}$ But these analyses are derived from a limited number of indicators, sometimes extracted from data which are unrepresentative of the general population. ${ }^{(5)}$ Also the comparison with employees has been a general one while differing situations in status call for a differentiation by subgroup. A comparison of working conditions between salaried and nonsalaried workers from the data of the Conditions de travail, 2005 survey (Dares), for example, shows the importance of such a differentiation. The results

(4) For example : InSERm (2011), chapter 5: "État de santé des travailleurs indépendants selon le secteur professionnel", pp. 83-97; HA-VINH et al. (2010, 2011).

(5) For example: the data on long-term illnesses (Affections de longue durée, $A L D$ ). 
highlight the similarities between the self-employed and employees engaged in the same areas of activity, including individual farmers and self-employed crafts workers on the one hand and salaried workers on the other (AlgaVA, VINCK, 2009). They thus reflect the lesser importance of status.

If proven, the hypothesis of a correlation between self-employment and relatively better health would indicate a singular mode of articulation between work and health that it would be of interest to study. Indeed, there is no reason to expect such a result, especially as it is well known that the self-employed are on average older than employees. This would raise the question of what mechanisms might explain this singularity. The first that comes to mind -which primarily motivates our investigations- refers to the social insurance system attached to the status of self-employment which is known to differ from that of employees. ${ }^{(6)}$ The health declarations of the selfemployed give precisely the opportunity to explore this rarely considered but certainly formative aspect in understanding the links between health and work. In part related to this, we can also study the specificity of this group's statements concerning health conditions or their specificity in health care behaviour, as some recent studies suggest (AMossé et al., 2012). In short, this documents the need for a research program which, however, necessitates as a first step establishing as rigorously as possible the reality of the relatively better health of the selfemployed. A part of this article is devoted to this question.

The hypothesis of the relatively better health of the self-employed is tested on the basis of statistical surveys conducted in representative samples of the general population which also offer a greater range of health indicators. The health characteristics discussed here are derived from these health indicators. It is reported by the workers and not inferred from the characteristics of their working conditions. ${ }^{(7)}$ Specifically, we have used the following surveys: Handicap Santé -volet ménages (HSM, handicap, health-household sample) organized by Drees and Insee ${ }^{(8)}$ in 2008, which surveyed 39,000 people, including 931 employed non-salaried workers; ${ }^{(9)}$ and Santé et itinéraire professionnel (SIP, health and professional career), organized by Drees and Dares in 2006, which surveyed 14,000 people, including 879

(6) For a detailed analysis of these differences, see AlgaVA, CAVAlin, Célérier (2011).

(7) For a detailed presentation of this option, see CAVALIN, CÉLÉrier (2012a) and for an examination of the different ways of understanding the links between work and health, see CAVALIN, CÉLÉRIER (2012b).

(8) Drees : Direction de la recherche, des études, de l'évaluation et des statistiques; Insee : Institut national de la statistique et des études économiques.

(9) This survey links the themes of health and handicaps and continues the decadal survey Santé 2003 and Handicaps Incapacités Dépendance (HID, 1998-2001). employed non-salaried workers. These two surveys provide a wealth of indicators which are quite sufficient for our project. The size of their respective samples also allows for studying the different populations in sufficient detail without many challenges to the statistical robustness of the results.

The study aimed at excluding three main statistical devices which could form an artificial correlation between employment status and health. First are the structural effects of other variables such as age and gender that are known to be decisive in declarations of health conditions and which directly affect the self-employed, as they are on average older than employees and are more often men. Second is the possible effect of the social gradient ${ }^{(10)}$ within the statutory group -like the known gradient among salaried employees from managerial personnel to workers- which might favourably distinguish the independent professions. Solid advances in the literature on this subject(11) indicate taking into account the personal PCS (Classification of Socioprofessional Categories) supplemented today by other social characteristics of individuals such as income (itself linked to PCS), education, and the social insurance status of the individual (TuBEuF, 2010) ${ }^{(12)}$ which seem to structure health declarations and health care behaviour. Finally, the last device to consider is a possible selection by health status ${ }^{(13)}$ at the moment one enters or exits the employment status, such as exists for night work.

Our analyses confirm and clarify the relative health advantage of the self-employed which can be considered as sufficiently robust to be a basis for a research program which will deepen our understanding of the question. These analyses reject the hypothesis of indirect structural effects or internal compensation between subgroups which the literature on health inequalities invites us to study. Where they exist, the inequality between individual farmers,

(10) This idea refers to what is also designated as social inequalities in health. The World Health Organisation (WHO) defines it in reference to a regular and general result:

"The data show that in general in a given country the more disadvantaged the socio-economic position of an individual, the worse is his health: this social gradient concerns the entire socio-economic scale, from top to bottom. It is a world-wide phenomenon which can be seen in low- and middle-income countries as well as those with high income. The social gradient indicates that health inequalities affect everyone." For a complete definition of the concept see the web site of the WHO: http://www.who.int/social_determinants/thecommission/ finalreport/key_concepts/en/

(11) Particularly CAmBors et al. (2008) for life expectancy and disability-free life expectancy and, more generally on the same theme, see the complete bibliography compiled by the Institut de recherche et documentation en économie de la santé (IRDES) in 2012 and available at the following address: http://www. irdes.fr/EspaceDoc/DossiersBiblios/InegalitesSocialesSante. pdf. See also BeH (2011).

(12) See also Chauvel (2001) for the complexity of the "social classes" approach.

(13) Also called the "effet du travailleur en bonne santé" or the "Healthy Worker Effect". 
merchants and self-employed crafts workers on the one hand and the self-employed professionals on the other are never as complete, nor do they always act in the same direction as those observed between management personnel and salaried workers. This non-conformity with a repeatedly and universally observed result is an unexpected consequence of our investigation, confirming the interest which the question presents and for which we now define the contours. There remains the possibility of a selection by health criteria which cannot be ruled out as strongly in the absence of longitudinal data. ${ }^{(14)}$

The available cross-sectional surveys are not, however, lacking in possibilities. We have used the retrospective data of the SIP survey, asking respondents about what they remember of their professional career and the health problems they have encountered. When health problems occur, the data describe a slight evolution from the nonsalaried status towards the salaried personnel one. However, the data is not sufficiently clear to demonstrate a healthy worker effect. The population and the size of the changes involved are low, and survey respondents' memory may be uncertain. However, efforts in this direction are far from being useless. They encourage to study the compared effects of the occurrence of a health problem on the course of a professional career according to the employment status and to take into consideration certain events such as sick leave or modulation of working hours. In these incidents we find some characteristics specific to the status of self-employed, both in terms of the type of work done (hours) as well as in the characteristics of their insurance systems (sick leave). In raising the question of a possible healthy worker effect, we are therefore already considering the sources of the health advantage found.

In presenting all of these analyses, our remarks are divided into two relatively independent sections concerning the issues addressed and the resources mobilized. The first considers the statistical finding of the relatively better health of the self-employed which we attempt to prove by distinguishing the effects of structure and the interaction of social inequalities in health. We also note some key dimensions of the temporal organization of self-employed activity that are specific to the group and may weigh as constraints on health. The second part presents the consequences of the considerations on the healthy worker effect and compares the situation of the self-employed to that of employees when illness strikes. We follow over several years the effects of illness on the course of their professional career, the nature and intensity of their use of sick leave and the extent of their ability to adjust their working time.

(14) The 2010 edition of the SIP survey will make this possible with 11,000 of the 14,000 of those who had answered the 2006 questionnaire having been questioned again for the more recent survey.

\section{The Health of the Self-Employed: the Other Specificity of a Heterogeneous Group}

As a diverse group, the self-employed pose a question at the outset concerning their defining characteristics, none of which having up to now achieved consensus agreement. The most commonly used, and which we will use ourselves despite its ambiguities, comes from public statistics. This is the category of non-salaried workers ${ }^{(15)}$ in contrast to wage labour, although there is not a perfect distinction between the two. This distinction is questionable as the border between self-employment and wage-earning sometimes seems to be a rather weak one (Rolle, 1988). Many legal decisions in France regularly recognize multiple forms of subjugation which are disguised under formal situations of legal "independence" (MAURIN et al., 1999; SuPIot, 2009). Conversely, some groups of employees such as managerial personnel and higher intellectual professions or even some intermediate professions enjoy a professional independence which is quite comparable to that which is supposed to characterize the self-employed. Finally, individuals often cross employment status borders themselves during their careers. The SIP survey of 2006 tells us that more often they cross over from-wage earners to self-employed, most of the self-employed $(71 \%)$ having already had an experience as wage-earners. The reverse evolution only applies to $5 \%$ of employees who say that they had gone through a period with the employment status of self-employed.

Based on the statistical convention adopted, some three million people make up the non-salaried group in 2010,(16) more than in 2009 and 2008. These three million represented $11 \%$ of the employed labour force, with an obvious -and for this group a systematic- imbalance between men (68\%) and women. ${ }^{(17)}$ The data collected in Table 1 complete the presentation of the group demonstrating its heterogeneity, presented here in terms of

(15) The Insee nomenclature groups together the selfemployed, those who declare helping a member of their family in his work without being paid (unpaid family workers), and non-salaried entrepreneurs who employ other workers.

The category is not without ambiguities, however, as it also includes general managers, minority managers and their partners. Although the "self-employed" workers do not exactly match the "non-salaried" group as they include some salaried workers in the French statistical nomenclature, in this text we will use the terms "self-employed" and "non-salaried" as approximate equivalents in accordance with the established French practice.

(16) Emploi en continu survey (EEC, Insee, 2010).

(17) Another internal imbalance among the self-employed: three quarters of the unpaid family workers are women while they represent 30 per cent of the self-employed and entrepreneurs (EEC, Insee, 2013). 
Table 1: Characteristics of Self-Employed by Component Sub-Categories

\begin{tabular}{|c|c|c|c|c|c|c|c|c|c|c|c|c|}
\hline & \multirow{2}{*}{$\begin{array}{c}\text { Population } \\
\text { (gross) }\end{array}$} & \multicolumn{5}{|c|}{ Standard of living (euros) } & \multicolumn{4}{|c|}{ Highest diploma obtained* } & \multicolumn{2}{|c|}{ Age } \\
\hline & & $\begin{array}{ll}10 \\
800\end{array}$ & $\begin{array}{c}{[800} \\
1,100\end{array}$ & $\begin{array}{l}{[1,100} \\
1,500\end{array}$ & $\begin{array}{l}{[1,500} \\
2,000\end{array}$ & $\begin{array}{l}{[2,000} \\
\text { and }+\end{array}$ & Brevet & $\begin{array}{l}\text { BEP } \\
\text { CAP }\end{array}$ & Bac & $\begin{array}{c}\text { Bac+ } 2 \\
\text { or }+\end{array}$ & average & median \\
\hline Individual farmers & 230 & $18 \%$ & $18 \%$ & $28 \%$ & $12 \%$ & $13 \%$ & $16 \%$ & $61 \%$ & $7 \%$ & $16 \%$ & 45 & 46 \\
\hline $\begin{array}{l}\text { Self-employed crafts } \\
\text { workers; merchants }\end{array}$ & 437 & $11 \%$ & $13 \%$ & $22 \%$ & $22 \%$ & $23 \%$ & $25 \%$ & $48 \%$ & $10 \%$ & $17 \%$ & 45 & 45 \\
\hline $\begin{array}{l}\text { Self-employed profes- } \\
\text { sionals and related }\end{array}$ & 146 & $4 \%$ & $4 \%$ & $8 \%$ & $13 \%$ & $62 \%$ & $5 \%$ & $8 \%$ & $6 \%$ & $81 \%$ & 46 & 47 \\
\hline “"Other” non-salaried & 103 & $5 \%$ & $8 \%$ & $13 \%$ & $33 \%$ & $30 \%$ & $7 \%$ & $14 \%$ & $14 \%$ & $65 \%$ & 44 & 44 \\
\hline Total non-salaried & 931 & $11 \%$ & $12 \%$ & $20 \%$ & $19 \%$ & $27 \%$ & $18 \%$ & $40 \%$ & $9 \%$ & $33 \%$ & 45 & 45 \\
\hline Total active employed & 8653 & $7 \%$ & $12 \%$ & $23 \%$ & $26 \%$ & $28 \%$ & $20 \%$ & $34 \%$ & $11 \%$ & $34 \%$ & 40 & 41 \\
\hline Total & 17322 & $13 \%$ & $13 \%$ & 22 & $22 \%$ & $23 \%$ & 27 & $31 \%$ & $13 \%$ & $28 \%$ & 41 & 41 \\
\hline
\end{tabular}

$*$ Brevet $=$ middle school diploma $; \mathrm{BEP}, \mathrm{CAP}=$ professional and vocational diplomas $; \mathrm{BAC}=$ high school diploma; $\mathrm{BAC}+2$ or $+=$ post-high school diplomas.

Reading note: 18 per cent of individual farmers receive an income per consumer unit of less than 800 euros while 4 per cent of self-employed professionals and related are in the same case.

Population: Residents in metropolitan France in ordinary households from 18 to 65 years old.

Source: Handicap Santé Ménages, 2008 survey, Insee-Drees.

living standards and diplomas (see the shaded boxes for each sub-category). ${ }^{(18)}$

\section{Working Time}

The diversity of this group is also confirmed in terms of the working conditions of the various components of non-salaried workers. The analyses confirm the importance of the actual activity for which, as we have seen, they are much closer to their equivalent wage-earners than they are to those who share their self-employed status (GolLAC, Volkoff, 2000). However, one dimension is an exception, bringing together all self-employed and distinguishing them from employees. This concerns the temporal organization of their professional activities, from the dual point of view of the time spent working and what is still called the influence of work over daily life. ${ }^{(19)}$ Indeed, regardless of the survey considered, non-salaried workers still report a greater number of hours worked than salaried workers do, even when they are managerial personnel. The last measure of the Emploi du temps survey (2010) records working time for the self-employed

(18) "The available information on self-employed income is approximate and difficult to use" (BESSIĖRE et al., 2011) due to the annual variations in the revenues of individual farmers, the revenue which a non-salaried worker may or may not pay himself according to the amount of profits he reinvests in his business, and the reliability of tax declarations. The limited relevance of the "standard of living" variable (INSEE, 2009) calls for looking at the patrimony of the self-employed. But this is not available in the declarative survey data on health used here.

(19) This indicator demonstrates a strong permeability between work time and time in private life. It includes five characteristics of work organisation which are given in detail in Table 2 and which, if three of these conditions are fulfilled, would indicate "a very strong influence of work on private life." as being 10.5 hours per week higher on the average than for employees (RICROCH, Roumier, 2011). (20)

Depending on employment status, the data from the Emploi en continu 2010 survey (Insee) also draw very different temporal profiles regarding reported work time and weekly rhythm. While weekly working hours for employees are centred, as expected, around the legal limit, those of non-salaried workers are much more spread out, extending to the 60-65 hour range (see Graph). The self-employed report a greater variability of their working time from one week to another, as in the data from the Conditions de travail survey (2005) which have also shown that they work a greater number of days of the week, usually including Saturday and, more rarely, Sunday. Adding other constraints linked to working time, the same survey has concluded that work has a ten times great influence over daily life for non-salaried workers than it has for employees (see Table 2). While it is true that the distinction by component of non-salaried workers shows disparities -especially between farmers and self-employed professionals-nevertheless the respective values are higher than those for employees. ${ }^{(21)}$

The regularity with which the literature records the differences in work time profiles of employees and non-salaried workers demonstrates the robustness of this characteristic and its quasi-structural character. In the typology of working time organization which Alain CHENU has distinguished from the data of the Emploi du temps survey of 1999, the working time of the self-employed is sufficient to distinguish them from all others interviewed, creating by themselves one of the six identified types (CHENU, 2002).

(20) That is a difference which is four hours less than during the previous equivalent survey conducted in 1999. This reduction can essentially be explained by a greater number of vacation days for the self-employed and not by a reduction in the average work time for a full work week.

(21) With the exception of night work which is always less. 
Graph: Working Time and Working Schedule
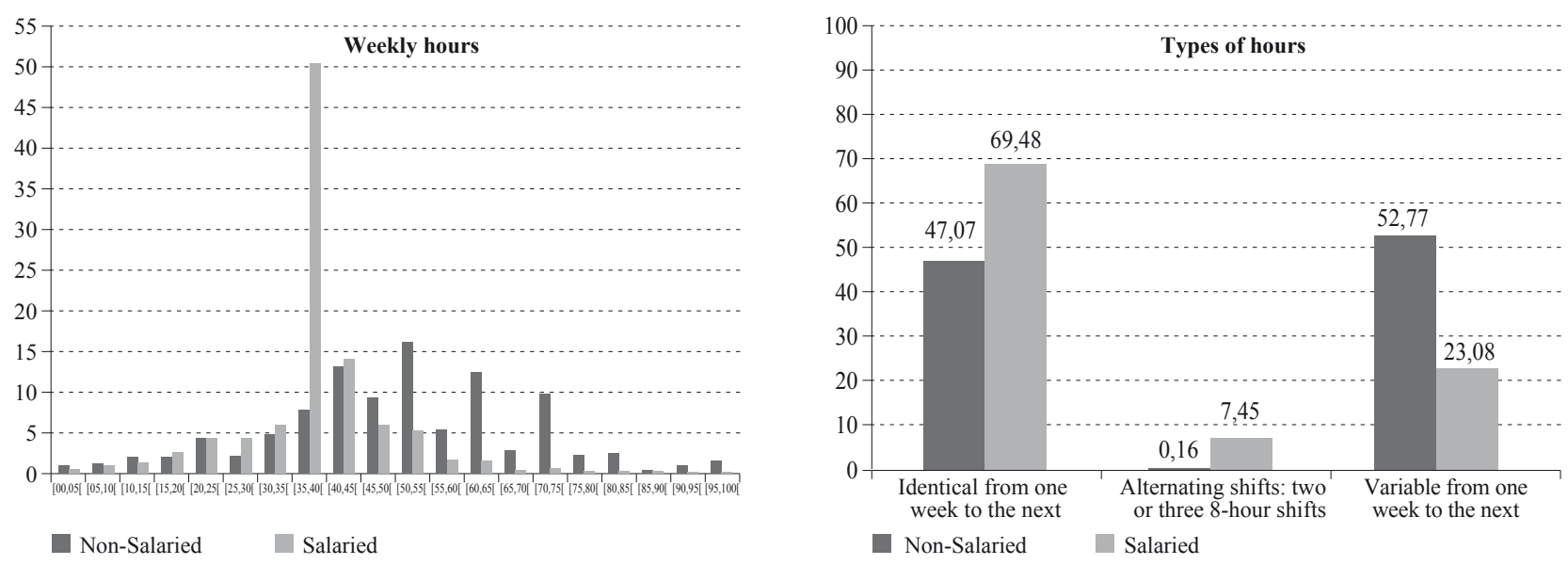

Reading note: The graph on the left compares the average number of work hours per week in the principal declared employment (regular employment) by employment status. The graph on the right compares the type of hours declared in the week and from one week to the next by employment status.

Population: Employed active population surveyed in interrogation rank 1 of the Enquête emploi en continu (2010).

Source: Enquête emploi en continu (Insee, 2010).

Table 2: Work Influence on Daily Life

\begin{tabular}{|l|c|c|c|c|c|c|c|c|}
\cline { 2 - 8 } \multicolumn{1}{l|}{} & \multirow{2}{*}{$\begin{array}{c}\text { Sala- } \\
\text { ried }\end{array}$} & $\begin{array}{c}\text { Non- } \\
\text { salaried }\end{array}$ & $\begin{array}{c}\text { Individual } \\
\text { farmers }\end{array}$ & $\begin{array}{c}\text { Self- } \\
\text { employed } \\
\text { crafts } \\
\text { workers }\end{array}$ & $\begin{array}{c}\text { Merchants } \\
\text { of firms } \\
\text { with } 10 \\
\text { employees } \\
\text { or more }\end{array}$ & $\begin{array}{c}\text { Self- } \\
\text { employed } \\
\text { professio- } \\
\text { nals }\end{array}$ & $\begin{array}{c}\text { Inter- } \\
\text { mediate } \\
\text { profes- } \\
\text { sions }\end{array}$ \\
\hline $\begin{array}{l}\text { Unable to modify work hours by } \\
\text { arrangement with colleagues in case of } \\
\text { unexpected events }\end{array}$ & $38.2 \%$ & $57.4 \%$ & $63.2 \%$ & $59.4 \%$ & $64.7 \%$ & $24.8 \%$ & $47 \%$ & $47.7 \%$ \\
\hline $\begin{array}{l}\text { Does not know work hours for the next } \\
\text { day }\end{array}$ & $5 \%$ & $13.3 \%$ & $19.4 \%$ & 11.4 & $11.5 \%$ & 12.3 & $10.4 \%$ & $9.5 \%$ \\
\hline Works more than 50 hours a week & $3.4 \%$ & $45.1 \%$ & $56.2 \%$ & $42.1 \%$ & $45.6 \%$ & $56.8 \%$ & $33.5 \%$ & $27.4 \%$ \\
\hline Works six days out of seven & $7.7 \%$ & $57.1 \%$ & $82.1 \%$ & $46.1 \%$ & $62 \%$ & $46.9 \%$ & $38 \%$ & $33.3 \%$ \\
\hline Generally works nights & $7.4 \%$ & $3.9 \%$ & $2.4 \%$ & $5.7 \%$ & $4.6 \%$ & $0 \%$ & $4.6 \%$ & $1.7 \%$ \\
\hline Generally works Sundays & $11.9 \%$ & $31.6 \%$ & $59.8 \%$ & $14.6 \%$ & $37.8 \%$ & $9.4 \%$ & $8.7 \%$ & $32.3 \%$ \\
\hline $\begin{array}{l}\text { Very strong work influence on daily } \\
\text { life (at least three of the above criteria) }\end{array}$ & $\mathbf{3 . 8} \%$ & $\mathbf{3 8 . 9} \%$ & $62.3 \%$ & $28.5 \%$ & $47.5 \%$ & $17.5 \%$ & $19.8 \%$ & $14.3 \%$ \\
\hline
\end{tabular}

Reading note: 38.9 per cent of non-salaried workers have a very strong work influence on their daily life according to the criteria measured by the Conditions de travail survey (2005).

Source: Conditions de travail Survey (2005), in Algava, Vinck (2009).

In this type are combined long working time hours, spread over at least six weekdays, with large variations from one week to another; work done at home being more common; very little night work; a relative autonomy of temporal organization detected through a greater freedom to decide when to take breaks; and the feeling of a constant lack of time. (22)

\section{Common Health Features}

We propose adding another characteristic to this distinctive feature of the self-employed regarding the temporal organization of their work: their declarations concerning their health. The proposal calls

(22) Several years earlier, Nathalie Missègue (2000) came to similar conclusions from the data of the Emploi survey of 2005 and of its ad hoc module on working time. for some clarification because, if we admit -sometimes a bit too rapidly- that the special commitment of the self-employed to their work could lead to a heavier work time load and a greater permeability between the various areas of their social life, the reasons that would lead them to share similar conditions of health are less clear.

At a descriptive level, we find that the relatively high average age of non-salaried workers (see Table 1) ${ }^{(23)}$ does not seem to affect their health as

(23) With the exception of farmers - and there are changes with the increase in life expectancy for the older generation and the rising costs of installation- the self-employed rarely begin their professional career in this status. They enter the status of selfemployed after previous experiences as wage-earners or, in the case of the self-employed professionals, after a long period of study (EvaIn, AMAR, 2006). 
one might expect. The responses they give to the three questions from the Mini European Health Module (MEHM) (24) (HSM 2008) put them in an intermediate position between salaried management personnel (the most advantaged) and salaried nonmanagerial employees. (25) Relying on an analysis "all things being equal" which helps separate out the structural effects, Table 3 indicates the nature of this health advantage. The analysis here includes the following control variables: age, gender, employment status (see Box), standard of living and supplemental health coverage, that is to say the fact of having or not having a complementary health insurance plan.

The self-employed have a lower likelihood of reporting combined symptoms (column I) and illnesses (column II) than do non-management employees. On these two points, managerial personnel enjoy an advantage comparable to that of the self-employed.

Their relative position is better concerning limitations experienced at work (column III), while the self-employed are close to the position of non-managerial employees. We should also note (column IV) the position of non-salaried workers and of managerial personnel concerning stress, the only health criterion for which they are less favourably positioned than non-managerial employees. This result confirms the value of the recently opened field of study on the stress of the self-employed (INSERM, 2011), but it should be read with caution. The HSM survey question on "stress" does not indicate any directive outline to this concept which remains rather ill-defined. The results of column $\mathrm{V}$ also emphasize the lower propensity for the self-employed to change occupation for health reasons, even though this characteristic is still less for managerial personnel. However, this latter measure remains fairly general and we would need further clarification to better understand the extent of the changes that are available to individuals.

(24) The Mini European Health Module (MEHM) is composed of three questions which structure Table 1 . These questions were fixed around the middle of the decade of the 2000 s which was the result of a long process of coordination between national and international (Eurostat) bodies in charge of following health-related questions. They are already present in most general population surveys and have been regularly exploited by researchers. Most of the documentation work concerning these surveys has been particularly based on medical or epidemiological questions which have illuminated the "objectivizing" or even predictive impact of declarations on subjectively perceived health status (Desalvo et al., 2005; Erdogan-CiftCI et al., 2010; MillunPalo et al., 1997).

(25) For a detailed comparative study of the responses to the Mini European Health Module see: Algava, CAvalin, CélérIer (2011) and particularly the table 3, page 10 .
Finally, the last two columns of the table (VI and VII) which compare the use of two types of health care have a dual interest. They identify the most distinctive health characteristic (or rather health care behaviour) of non-salaried workers and suggest that their relative advantage differs in kind from that of managerial personnel. With given characteristics, the latter do indeed have a lower likelihood of reporting illness, multiple symptoms or limitations than do other employees, while at the same time utilising more health care, including consultations of medical specialists. In other words, as the work on health inequalities has consistently demonstrated, their health advantage is obtained, or accompanied by, stronger preventive and curative practices.

\section{Box \\ Details of the Subgroups of Salaried and Non-Salaried Workers as Defined to Make Logistic Regressions}

In these logistic regressions, the employment status is based in the first place, as indicated above, on the "STATUT" variable which, in the Insee surveys, includes among "non-salaried" workers, those who are "self-employed" (STATUT= 5), "unpaid family workers" (STATUT= 6), "salaried entrepreneurs, general managers, minority managers or partners" (STATUT= 7). On the basis of this variable, the tables 3 and 4 distinguish wageearners and non-wage earners and, inside of these groups, identify "managerial personnel and higher intellectual professions" by the socioprofessional group " 3 ", the other wage-earners being attached to all the other groups in the PCS nomenclature. Table 5 goes further, distinguishing salaried and non-salaried workers with the employment status and PCS as follows:

Non-salaried:

- Farmers, merchants and crafts workers: STATUT = 5, 6, 7 and CS = 10, 21, $22(n=667)$

- Self-employed professionals, managerial, professional and technical workers and higher intellectual professions, heads of firms with 10 or more employees: STATUT $=5,6,7$ and $\mathrm{CS}=23,31,32,36$ $(n=146)$;

- "Other non-salaried": STATUT $=5,6,7$ and CS $=$ $41,46,47,48,54,55,56,61,66,69$, ( $n=103)$.

Salaried:

- Salaried managerial personnel and higher intellectual professionals: STATUT $=1,2,3,4$ and $\mathrm{CS}=$ 31, 32, 36 ( $n=1033)$;

- Salaried intermediate professions: STATUT: 1, 2, 3,4 and $C S=41,46,47,48(n=1789)$;

- Salaried employees and workers: STATUT= 1, 2, 3, 4 and $C S=51,54,55,56,61,66,69(n=4784)$. 
Table 3: Probability of Declaring a Number of Health Characteristics and of Utilizing Health Care According to Employment Status

\begin{tabular}{|c|c|c|c|c|c|c|c|}
\hline & I & II & III & IV & $\mathbf{V}$ & VI & VII \\
\hline $\begin{array}{l}\text { Probability of } \\
\text { declaring : }\end{array}$ & $\begin{array}{c}4 \text { or more } \\
\text { symptoms } * * \\
\text { out of } 9 \\
\text { (last } 12 \\
\text { months) }\end{array}$ & $\begin{array}{l}\text { Number of } \\
\text { illnesses } \\
\text { reclassified } \\
\text { ICD higher } \\
\text { than or equal } \\
\text { to } 2(\diamond) \\
\text { during a life- } \\
\text { time }\end{array}$ & $\begin{array}{l}\text { Being limited } \\
\text { in one's work } \\
\text { for health } \\
\text { reasons }\end{array}$ & $\begin{array}{c}\text { Symptoms of } \\
\text { stress (last } 12 \\
\text { months) }\end{array}$ & $\begin{array}{l}\text { Has changed } \\
\text { profession } \\
\text { for medical } \\
\text { reasons at } \\
\text { least once in } \\
\text { one's active } \\
\text { life }\end{array}$ & $\begin{array}{l}\text { Has consul- } \\
\text { ted a general } \\
\text { practitioner } \\
\text { at least once } \\
\text { during the last } \\
12 \text { months }\end{array}$ & $\begin{array}{l}\text { Has consulted } \\
\text { a medical } \\
\text { specialist at } \\
\text { least once } \\
\text { during the last } \\
12 \text { months }\end{array}$ \\
\hline $\begin{array}{l}\text { Non-salaried } \\
(\mathrm{n}=931)\end{array}$ & $0.65^{*}$ & $0.77 *$ & ns & $1.27 *$ & $0.60 *$ & $0.52 *$ & $0.84 *$ \\
\hline $\begin{array}{l}\text { Managerial } \\
\text { and higher } \\
\text { intellectual } \\
\text { professions } \\
(\mathrm{n}=1033)\end{array}$ & $0.70^{*}$ & $0.80 *$ & $0.44 *$ & $1.43^{*}$ & $0.46^{*}$ & ns & $1.23 *$ \\
\hline $\begin{array}{l}\text { Salaried, but } \\
\text { not manage- } \\
\text { rial or higher } \\
\text { intellectual } \\
\text { professions } \\
(\mathrm{n}=6689)\end{array}$ & Ref. & Ref. & Ref. & Ref. & Ref. & Ref. & Ref. \\
\hline
\end{tabular}

* Odds ratio significant at the 5 percent threshold.

** 4 symptoms including: sleep disorders, fatigue, eating disorders, chronic heartburn, reflux, heart palpitations, tachycardia, fainting, vertigo, dizzy spells, blackouts, shortness of breath, colitis, intestinal pains, stress.

$(\diamond)$ The median and average numbers of chronic illness after reclassification ICD (International Classification of Diseases) among those 18 to 65 years old are 1 and 1.67 (among active employed 18 to 65 years old it is 1 and 1.46 respectively); 41 per cent of those 18 to 65 years old (and 38 per cent of active employed 18 to 65 years old) have two or more diseases classified ICD during their lifetime. Analysis at a given age avoids reading the growth in the number of illnesses as the fruit of advancing age (the mechanical effect of time passing plus the growing probability of illness with advancing age).

Reading note: Non-salaried workers have a 35 per cent lower probability than salaried non-managerial, technical and profession workers at a given age, gender, employment status, standard of living and complementary medical insurance, of having four or more symptoms (in a list of $9)$ for the 12 months preceding the survey.

Population: Active employed, 18-65 years.

Source: HSM 2008.

For self-employed workers, the relative health advantage clearly does not flow from such practices. Either their needs ${ }^{(26)}$ to utilise health care are less than those of other groups or they delay more in utilising health care with the risk, in this case, of developing poor health in the long term. The reasons they give for not utilising health care at least once during the previous twelve months are significantly associated with the part that work takes up in their daily life. While managerial personnel and other employees mainly evoke the cost of health care (54\% and $52 \%$ respectively), the self-employed refer to costs $(37 \%)$ as frequently as to a lack of time (38\%). ${ }^{(27)}$

The less favourable character of social security for self-employed health care can also affect their

(26) At least those they identify as such.

(27) HSM 2008 (Drees-Insee). lower medical consumption. (28) In fact, our analyses conducted "all things being equal" demonstrate that, by incorporating the presence or absence of complementary health care insurance in the controlled variables, the self-employed status is less frequently associated with a complementary insurance. ${ }^{(29)}$ The "employment status" effect is therefore probably linked to a "social insurance status" effect, thus confirming that insurance status plays a crucial role in relation to the health care of individuals. This result confirms our interest in the subject and calls for continuing the investigation through appropriate surveys. ${ }^{(30)}$

(28) The general regime is still the most protective one (TAButeau, 2010). The amount as well as the duration of compensation is greater. Compensation for accidents and occupational diseases does not exist for those affiliated to the RSI (Régime social des indépendants which is the self-employed insurance plan) who either do not enjoy the possibility of modulating their work time to help their return to work following an illness (e. g., therapeutic part-time work). For the details of the differences between the regimes, see Algava, Cavalin, CÉLÉRIER (2011).

(29) In spite of the 1994 Madelin Law which provided for tax deductions for the charges (Perronnin et al., 2011).

(30) For example, see particularly the biennial survey Santé et protection sociale (ESPS) directed by the Irdes. 
Table 4: Probability of Declaring a Number of Health Characteristics and of Utilizing Health Care According to Employment Status

\begin{tabular}{|c|c|c|c|c|c|}
\hline & \multicolumn{3}{|c|}{ Mini European Health Module (MEHM) } & \multirow[b]{2}{*}{ IV } & \multirow[b]{2}{*}{$\mathbf{V}$} \\
\hline & I & II & III & & \\
\hline Probability of declaring : & $\begin{array}{l}\text { Health seen } \\
\text { as very good, } \\
\text { fairly good or } \\
\quad \text { good }\end{array}$ & $\begin{array}{l}\text { Currently has } \\
\text { at least one } \\
\text { chronic disease }\end{array}$ & $\begin{array}{l}\text { Incapacitated } \\
\text { (strongly or } \\
\text { not) for health } \\
\text { reasons }\end{array}$ & $\begin{array}{l}\text { Declares } 4 \text { or } \\
\text { more symp- } \\
\text { toms } * * \text { out of } 9 \\
\text { (last } 12 \text { months) }\end{array}$ & $\begin{array}{l}\text { Has a number } \\
\text { of diseases } \\
\text { classified ICD } \\
\text { higher than or } \\
\text { equal to } 2(\diamond) \\
\text { (life time) }\end{array}$ \\
\hline $\begin{array}{l}\text { Farmers, merchants (and related), } \\
\text { crafts workers }(n=667)\end{array}$ & $\begin{array}{c}1.69^{*} \\
{[1.05 ; 2.76]}\end{array}$ & $\begin{array}{c}0.95 \\
{[0.79 ; 1.13]}\end{array}$ & $\begin{array}{c}0.69^{*} \\
{[0.54 ; 0.88]}\end{array}$ & $\begin{array}{c}0.70^{*} \\
{[0.55 ; 0.90]}\end{array}$ & $\begin{array}{c}0.82 * \\
{[0.69 ; 0.98]}\end{array}$ \\
\hline $\begin{array}{l}\text { Self-employed professionals, mana- } \\
\text { gerial, professional and technical } \\
\text { workers and higher intellectual profes- } \\
\text { sions, heads of firms with } 10 \text { or more } \\
\text { employees }(n=146)\end{array}$ & $\begin{array}{c}2.37 \\
{[0.67 ; 8.33]}\end{array}$ & $\begin{array}{c}1.01 \\
{[0.71 ; 1.43]}\end{array}$ & $\begin{array}{c}0.96 \\
{[0.61 ; 1.52]}\end{array}$ & $\begin{array}{c}0.69 \\
{[0.42 ; 1.15]}\end{array}$ & $\begin{array}{c}0.86 \\
{[0.61 ; 1.21]}\end{array}$ \\
\hline Other non-salaried $(n=103)$ & $\begin{array}{c}1.42 \\
{[0.45 ; 4.44]}\end{array}$ & $\begin{array}{c}0.57^{*} \\
{[0.36 ; 0.88]}\end{array}$ & $\begin{array}{c}0.55 \\
{[0.30 ; 1.02]}\end{array}$ & $\begin{array}{c}0.34^{*} \\
{[0.17 ; 0.67]}\end{array}$ & $\begin{array}{c}0.37^{*} \\
{[0.24 ; 0.59]}\end{array}$ \\
\hline $\begin{array}{l}\text { Managerial and higher intellectual } \\
\text { professions }(\mathrm{n}=1033)\end{array}$ & $\begin{array}{c}1.88^{*} \\
{[1.13 ; 3.14]}\end{array}$ & $\begin{array}{c}0.94 \\
{[0.81 ; 1.09]}\end{array}$ & $\begin{array}{c}0.61^{*} \\
{[0.49 ; 0.77]}\end{array}$ & $\begin{array}{c}0.71 * \\
{[0.58 ; 0.87]}\end{array}$ & $\begin{array}{c}0.78^{*} \\
{[0.68 ; 0.91]}\end{array}$ \\
\hline Intermediary professions $(\mathrm{n}=1789)$ & $\begin{array}{c}1.65^{*} \\
{[1.13 ; 2.39]}\end{array}$ & $\begin{array}{c}1.09 \\
{[0.97 ; 1.23 ;]}\end{array}$ & $\begin{array}{c}0.83^{*} \\
{[0.71 ; 0.98]}\end{array}$ & $\begin{array}{c}1.00 \\
{[0.86 ; 1.15]}\end{array}$ & $\begin{array}{c}0.96 \\
{[0.85 ; 1.07]}\end{array}$ \\
\hline \multirow[t]{2}{*}{ Workers and employees $(n=4784)$} & Ref. & Ref. & Ref. & Ref. & Ref. \\
\hline & VI & VII & VIII & IX & $\mathbf{X}$ \\
\hline Probability of declaring : & $\begin{array}{l}\text { Limited at } \\
\text { work for health } \\
\quad \text { reasons }\end{array}$ & $\begin{array}{l}\text { Symptoms of } \\
\text { stress (last } \\
12 \text { months) }\end{array}$ & $\begin{array}{l}\text { Has changed } \\
\text { profession } \\
\text { at least once } \\
\text { during active } \\
\text { life for medical } \\
\text { reasons }\end{array}$ & $\begin{array}{l}\text { Has consulted } \\
\text { a general prac- } \\
\text { titioner at least } \\
\text { once in the last } \\
12 \text { months }\end{array}$ & $\begin{array}{l}\text { Has consulted a } \\
\text { medical specia- } \\
\quad \text { list at least } \\
\text { once in the last } \\
12 \text { months }\end{array}$ \\
\hline $\begin{array}{l}\text { Farmers, merchants (and related), } \\
\text { crafts workers }(n=667)\end{array}$ & $\begin{array}{c}0.83 \\
{[0.62 ; 1.11]}\end{array}$ & $\begin{array}{c}1.41^{*} \\
{[1.19 ; 1.66]}\end{array}$ & $\begin{array}{c}0.38^{*} \\
{[0.22 ; 0.67]}\end{array}$ & $\begin{array}{c}0.58^{*} \\
{[0.48 ; 0.72]}\end{array}$ & $\begin{array}{c}0.88 \\
{[0.74 ; 1.05]}\end{array}$ \\
\hline $\begin{array}{l}\text { Self-employed professionals, mana- } \\
\text { gerial and higher intellectual profes- } \\
\text { sions, heads of firms with } 10 \text { or more } \\
\text { employees }(n=146)\end{array}$ & $\begin{array}{c}0.47 \\
{[0.22 ; 1.02]}\end{array}$ & $\begin{array}{c}2.03 * \\
{[1.45 ; 2.83]}\end{array}$ & $\begin{array}{c}1.59 \\
{[0.80 ; 3.15]}\end{array}$ & $\begin{array}{c}0.44 * \\
{[0.30 ; 0.63]}\end{array}$ & $\begin{array}{c}1.26 \\
{[0.89 ; 1.79]}\end{array}$ \\
\hline Other non-salaried $(n=103)$ & $\begin{array}{c}0,24 * \\
{[0,08 ; 0,78]}\end{array}$ & $\begin{array}{c}1,10 \\
{[0.75 ; 2.61]}\end{array}$ & $\begin{array}{c}0.60 \\
{[0.18 ; 2.05]}\end{array}$ & $\begin{array}{c}0.59^{*} \\
{[0.36 ; 0.94]}\end{array}$ & $\begin{array}{c}1.02 \\
{[0.67 ; 1.54]}\end{array}$ \\
\hline $\begin{array}{l}\text { Managerial and higher intellectual } \\
\text { professions }(n=1033)\end{array}$ & $\begin{array}{c}0.38^{*} \\
{[0.27 ; 0.54]}\end{array}$ & $\begin{array}{c}1.72 * \\
{[1.49 ; 1.98]}\end{array}$ & $\begin{array}{c}0.43^{*} \\
{[0.26 ; 0.71]}\end{array}$ & $\begin{array}{c}0.92 \\
{[0.76 ; 1.12]}\end{array}$ & $\begin{array}{c}1.42 * \\
{[1.22 ; 1.66]}\end{array}$ \\
\hline Intermediary professions $(\mathrm{n}=1789)$ & $\begin{array}{c}0.73 * \\
{[0.59 ; 0.91]}\end{array}$ & $\begin{array}{c}1.47^{*} \\
{[1.31 ; 1.65]}\end{array}$ & $\begin{array}{c}0.80 \\
{[0.58 ; 2.09]}\end{array}$ & $\begin{array}{c}1.19 \\
{[1.00 ; 1.40]}\end{array}$ & $\begin{array}{c}1.37^{*} \\
{[1.21 ; 1.55]}\end{array}$ \\
\hline Workers and employees $(n=4784)$ & Ref. & Ref. & Ref. & Ref. & Ref. \\
\hline
\end{tabular}

* Odds ratio significant at the 5 percent threshold.

** 4 symptoms including: sleep disorders, fatigue, eating disorders, chronic heartburn, reflux, heart palpitations, tachycardia, fainting, vertigo, dizzy spells, blackouts, shortness of breath, colitis, intestinal pains, stress.

$(\diamond)$ The median and average numbers of chronic illness after reclassification ICD (International Classification of Diseases) among those 18 to 65 years old are 1 and 1.67 (among active employed 18 to 65 years old it is 1 and 1.46 respectively); 41 per cent of those 18 to 65 years old (and 38 per cent of active employed 18 to 65 years old) have two or more diseases classified ICD during their lifetime. Analysis at a given age avoids reading the growth in the number of illnesses as the fruit of advancing age (the mechanical effect of time passing plus the growing probability of illness with advancing age).

Reading note: A farmer, merchant or crafts worker with a given age, gender, employment status, standard of living and complementary medical insurance multiplies by 1.69 his chance of declaring that he is in very good, fairly good or good health (question 1 of the mini-module) as compared to a worker or employee.

Population: Active employed, 18-65 years old.

Source: HSM 2008.

To validate the idea of a relative health advantage for non-salaried workers, we still have to rule out a statistical artefact that might mix together very different, even polarized, health situations among the components of the group. On the one hand are the self-employed professionals whose income and diplomas are close to those of managerial workers and on the other are the self-employed crafts workers, merchants, and individual farmers whose health may be as unfavourable as that of workers, for example, with whom they share many of the same working conditions. In other words, one might think that the relatively good health of nonsalaried workers would result in large part from the social inequalities in health which are internal to the group, the most favoured within it (by diplomas 
or standard of living) pulling up the average health performance of the whole group.

Consequently, we have tested the internal diversity of non-salaried workers, distinguishing three groups within them: individual farmers-selfemployed-crafts workers-merchants; self-employed professionals and related, heads of businesses with ten or more employees; and "other" non-salaried workers. (31) We have compared these groups to all salaried employees within which we have also distinguished three groups: salaried managerial personnel and higher intellectual professionals; intermediate professionals; and employees and workers. Table 4 gives the probabilities for declarations concerning ten health indicators by taking the subgroup of workers and employees as the reference independent variable of employment status. Overall, we can see that the self-employed report relatively good health for all indicators in columns I to VIII of the table. The self-employed professionals and related do not stand out in this case and, except for reports of stress (column VII ${ }^{(32)}$ ), are not on the same level as that of salaried management personnel. For these indicators, individual farmers, self-employed crafts workers and merchants have relatively more favourable positions than expected, in many respects close to that of the salaried intermediate professions.

Considering the overall active population of eighteen to sixty-five years old, we find the results anticipated by research on health inequalities. Managerial personnel and higher intellectual professionals stand out with a significant advantage. For the vast majority of our first eight indicators, they have indeed a better chance of reporting better health than the other groups of actively employed, other characteristics being equal. This result which is readable in terms of PCS is very clear and, once again, we see the known gradient of health inequalities.

However, this gradient is not exactly observable when we take into account employment status. While taking the "workers and employees" employment status as a reference, no matter what the given characteristics, salaried managerial personnel and

(31) These "other" non-salaried illustrate the diversity of the self-employed status. While they have the status of "selfemployed" in the sense of the Insee variable which we have utilised, they have declared themselves to be in the socioprofessional category of group 4 (intermediary professions), group 5 (employees) or group 6 (workers). This "other" non-salaried group include 103 people in the 2008 HSM survey with a great diversity of professional activities, as demonstrated by the socioprofessional categories listed in the box. Note, for example, the intermediate professions: in health care (nurses, physiotherapists); advertising and communications; hostesses and security workers; translators; and specialised occupations in stock raising and forestry.

(32) Table 3 has already indicated this in reference to the declared symptoms of stress, that is, the nearly universal increased probability of these symptoms outside of the group of workers and employees. non-salaried self-employed professionals do not have, as we have noted, the same social health advantage. To check this point, we have made additional logistical regressions incorporating the same health indicators as dependent variables, the same independent variables and the same subgroups as in Table 4, but this time operating separately on the sub-field of non-salaried workers on the one hand and salaried employees on the other. We have compared the health inequalities between managerial personnel and workers-employees (within the sub-field of wage-earners) to those that distinguish the self-employed professionals from the individual farmers, self-employed crafts workers and merchants (within the sub-field of the self-employed).

The results confirm the previous ones, namely the remarkable advantages for managerial personnel(33) but no significant differences among non-salaried workers, for nine of the ten indicators considered. Only the probability of having changed profession for medical reasons at least once in his life clearly distinguishes the self-employed professional (34) but this result, based on a population which is too small, does not have sufficient statistical robustness to be relied on without reservation. In any case, we clearly see that the PCS variable is no longer universally operative when employment status is taken into account. This is a robust result of our analysis.

\section{When IIIness Strikes}

The last mechanism which may play a role in the relatively better health of the self-employed concerns the selection process which operates when one enters or leaves the employment status. Those who are in poor health or who might feel less confident on this point might avoid joining an employment status that would expose them to greater risks and they would leave it with the first doubts. So in this status we would find "health-selected" workers which would explain their generally more favourable position despite a relatively high average age. Our investigations on this point are severely limited by the lack of longitudinal data. To approach this question, however, we have used the retrospective data from the SIP (2006) survey which asked the respondents to restore their career paths from memory and to identify health problems they say they have encountered during their lifetime. With due caution imposed through the use of such

(33) Odds ratios for managerial personnel and higher intellectual professions (reference: workers and employees), respecting the order of columns I to X of Table 4: $1.79 ; \mathrm{ns} ; 0.62 ; 0.73$; $0.80 ; 0.39 ; 1.78 ; 0.42 ; \mathrm{ns} ; 1.43$.

(34) Odds ratio: 4.96 (within the sub-field of non-salaried workers, the referenced status was individual farmers, selfemployed crafts workers and merchants). 
material, we have sought the comparative effects of illness in relation to employment status.

Indeed, while the self-employed enjoy relatively good health despite their age, they have not, however, been spared illness, which affects them as it does other groups. To give an example -also related to their average age - they are affected by 9 of the 60 cancer cases identified in the HSM survey in 2008, while managerial personnel whose numbers are equivalent are only affected by 4 of them. This second part of our article therefore explores what happens when -whether salaried or self-employed- illness, disability or limitations of various kinds disturb the course of working life. We have monitored the effects of these problems on the course of a professional career by selecting three a priori possible effects for which the survey data provided the most appropriate information. We treat the first one in the register of the reorientation of career, which the literature discusses in terms of the increasingly precarious nature of employment situations in case of illness. The next two effects, the temporary interruption of professional activity and the modulation of the temporal organization of work, are grouped and analysed as arrangements of professional activities.

\section{The Effects on Professional Career}

The impact of a particular illness on the progression of a professional career is a question posed by all disease specialists in their monitoring of the evolution of those who have fallen ill. The observation is worthwhile, even if this concern remains marginal in relation to following the effects of treatment, especially if the illness has high lethal risks. The cancers give an archetypal example (CÉLÉRIER, 2008). The Anglo-Saxon current particularly questions the effects of chronic diseases in terms of the return to work, wholly or partially accomplished and more or less "delayed" (SPelten et al., 2002). In France, the reflection has been broader and marked by the observation made since the 1980s of large health differences between the employed and the unemployed, with the latter always having a health condition less favourable than the former (KHLAT, SERmet, 2004).

Comparative causality research underlying this observation has installed a tradition of analysing the impact of illness as to unemployment or inactivity most often detailing the situations for women and men (Mesrine, 2000; SAurel-Cubizolles, 2001; MALENFANT et al., 2004; Jusot et al., 2006). These studies generally conclude with the cost for the patients, although estimates vary widely from one study to another, and they can also be read in an encouraging light. A recent study on the impact of cancer shows that many people survive it today and a large majority of them live in conditions close to those of the general population two years after diagnosis (EICHEnBaum-Volin et al., 2008, pp. 126-127). ${ }^{(35)}$

Following the line of research opened by the work in France, we have investigated three types of reorientations of professional careers: unemployment, inactivity and unstable employment, (36) to which we have added a change of employment status from non-salaried workers to wage-earners and vice versa. We have started from illnesses as reported by SIP respondents, distinguishing those who reported according to whether they had held a salaried or non-salaried position in the year (n-1) for an illness that started in the year (n). We have recorded their respective positions at the end of this year (n), at one year $(n+1)$, and at two years $(n+2)$ after the onset of the illness. Table 5 presents the results, distinguishing the evolution of the selfemployed on the left from that of salaried employees on the right. The table also distinguishes whether or not they have reached fifty years of age, since the passage to inactivity when an illness strikes is more common at a later age.

In total, some 7,500 illnesses were reported ${ }^{(37)}$ in SIP which in its large majority involved salaried employees and, more specifically, employees under fifty years old who were by far the most represented in the survey. The data in Table 5 reveal two significant results. On the one hand, illness does not involve movement towards self-employment on the part of salaried employees, regardless of their age. (38) If there is any movement, it is from the non-salaried to the salaried employees, at least for the youngest of those who were non-salaried. If short-term and long-term salaried jobs are added together, some $8 \%$ of the youngest non-salaried changed employment status two years after the health incident. This observation is rather in the sense of a healthy worker effect. However, it cannot completely decide the question.

(35) There nevertheless remains the disadvantage for manual workers who are always severely penalized by illness even when there is a favourable prognosis.

(36) The SIP survey defines long term employment as having held the same job for more than five years and short term employment as less than five years with occasional periods of unemployment or inactivity of less than one year. Unemployment itself was defined as lasting more than one year and inactivity as having left all employment for one year minimum.

(37) We have not taken into account the future of those persons who are in short term employment at n- 1 (1,642 cases of illness declared). The figures at points $n, n+1$ and $n+2$ on the "Short Term Employment" line of Table 5 only list the entry of wage earners and non-wage earners into this type of employment. (38) Qualitative surveys sometimes present the passage to selfemployment as a solution applied by persons who are ill. For those who declare having a cancer, see CHASSAING et al. (2011). 
Table 5: Professional Situation the Year of an Illness and One and Two Years Later as a Function of Age and Employment Status One Year Before the Illness

\begin{tabular}{|l|c|c|c|}
\hline $\begin{array}{c}\text { Non- } \\
\text { salaried } \\
\text { at n- 1, } \\
\text { 50 years } \\
\text { or older } \\
\text { (n= 434) }\end{array}$ & $\mathrm{n}$ & $\mathrm{n}+1$ & $\mathrm{n}+2$ \\
\hline & $\%$ & $\%$ & $\%$ \\
\hline $\begin{array}{l}\text { Unem- } \\
\text { ployed }\end{array}$ & 1 & 1 & 0 \\
\hline Inactive & 24 & 36 & 46 \\
\hline $\begin{array}{l}\text { Non-sala- } \\
\text { ried }\end{array}$ & 73 & 61 & 52 \\
\hline Salaried & 0 & 0 & 0 \\
\hline $\begin{array}{l}\text { Short-term } \\
\text { employ- } \\
\text { ment }\end{array}$ & 1 & 1 & 1 \\
\hline
\end{tabular}

\begin{tabular}{|l|c|c|c|}
\hline $\begin{array}{c}\text { Salaried } \\
\text { at n- 1, } \\
\text { 50 years } \\
\text { or older } \\
\text { (n= 1817) }\end{array}$ & $\mathrm{n}$ & $\mathrm{n}+1$ & $\mathrm{n}+2$ \\
\hline & $\%$ & $\%$ & $\%$ \\
\hline $\begin{array}{l}\text { Unem- } \\
\text { ployed }\end{array}$ & 1 & 2 & 4 \\
\hline Inactive & 22 & 36 & 48 \\
\hline $\begin{array}{l}\text { Non-sala- } \\
\text { ried }\end{array}$ & 0 & 0 & 0 \\
\hline Salaried & 76 & 61 & 48 \\
\hline $\begin{array}{l}\text { Short-term } \\
\text { employ- } \\
\text { ment }\end{array}$ & 0 & 1 & 0 \\
\hline
\end{tabular}

\begin{tabular}{|l|c|c|c|}
\hline $\begin{array}{c}\text { Non- } \\
\text { salaried } \\
\text { at n- 1, } \\
\text { less than } \\
\text { 50 years } \\
\text { (n= 554) }\end{array}$ & $\mathrm{n}$ & $\mathrm{n}+1$ & $\mathrm{n}+2$ \\
\hline & $\%$ & $\%$ & $\%$ \\
\hline $\begin{array}{l}\text { Unem- } \\
\text { ployed }\end{array}$ & 1 & 1 & 0 \\
\hline Inactive & 8 & 13 & 15 \\
\hline $\begin{array}{l}\text { Non-sala- } \\
\text { ried }\end{array}$ & 90 & 82 & 77 \\
\hline Salaried & 0 & 1 & 4 \\
\hline $\begin{array}{l}\text { Short-term } \\
\text { employ- } \\
\text { ment }\end{array}$ & 1 & 2 & 4 \\
\hline
\end{tabular}

\begin{tabular}{|l|c|c|c|}
\hline $\begin{array}{c}\text { Salaried } \\
\text { at n- 1, } \\
\text { less than } \\
\text { 50 years } \\
(\mathbf{n}=\mathbf{4 6 7 6 )}\end{array}$ & $\mathrm{n}$ & $\mathrm{n}+1$ & $\mathrm{n}+2$ \\
\hline & $\%$ & $\%$ & $\%$ \\
\hline $\begin{array}{l}\text { Unem- } \\
\text { ployed }\end{array}$ & 1 & 2 & 2 \\
\hline Inactive & 8 & 13 & 18 \\
\hline $\begin{array}{l}\text { Non-sala- } \\
\text { ried }\end{array}$ & 0 & 0 & 0 \\
\hline Salaried & 89 & 83 & 77 \\
\hline $\begin{array}{l}\text { Short-term } \\
\text { employ- } \\
\text { ment }\end{array}$ & 1 & 2 & 3 \\
\hline
\end{tabular}

Reading note: For all illnesses declared by non-salaried persons in long-term employment aged 50 or more in the year n- 1 , some 46 per cent of those persons were inactive in $n+2$.

Population: All diseases affecting persons in long-term employment, salaried or non-salaried in the previous year $(\mathrm{n}=7481)$.

Source: SIP 2006 (Drees-Dares).

First, it only affects one side of the issue by ignoring, by definition, healthy employees who may have become self-employed. Since this observation took place two years after the illness, it may result from other causes, including short-term ones, ${ }^{(39)}$ and the effect may therefore have been attenuated. The second result in Table 5 stems from the comparison of the upper and lower parts of the table -both older and younger than fifty years old- hence the structural character of age, which is greater than that of employment status. The evolution of salaried and non-salaried workers over fifty years old are similar and logically oriented towards inactivity which is probably, in this case, a form of retirement. We find the same similarity for the youngest group, although salaried employees who have been ill are found to be more frequently unemployed than their non-salaried counterparts.

(39) Without, of course, taking into account the problems of memory.
On the question of career reorientation, we can also judge the risk of unemployment following an illness by controlling several variables: the age at the onset of an illness; the gender; the type of disease; and the employment status in the year preceding the disease. Detailed in Table 6, this risk is not significantly different for the self-employed from what it is for salaried employees in long-term employment, the year of the occurrence of the disease, as well as for the following year. It only becomes significant two years later, when the probability of the selfemployed leaving employment is reduced by one third as compared to that of a salaried employee on long-term employment with all other characteristics being equal. The clearest effect as demonstrated in Table 6, however, concerns employment instability which severely aggravates the risk of job loss, rather than the employment status itself. Falling ill while working in unstable employment multiplies the chance of leaving employment by almost four times.

Table 6: Leaving Employment in the Years Following the Onset of a Medical Problem

\begin{tabular}{|l|c|c|c|c|c|c|}
\hline \multirow{2}{*}{$\begin{array}{c}\text { Situation one } \\
\text { year prior } \\
\text { to the onset } \\
\text { of a medical } \\
\text { problem }\end{array}$} & \multicolumn{4}{|c|}{ Per cent of those no longer employed } \\
\cline { 2 - 7 } & $\begin{array}{c}\text { Year of the start of } \\
\text { a medical problem }\end{array}$ & $\begin{array}{c}\text { Following } \\
\text { year }\end{array}$ & \multicolumn{2}{|c|}{$\begin{array}{c}\text { Two years } \\
\text { later }\end{array}$} \\
\cline { 2 - 7 } & In & OR* & In $\%$ & OR* & In \% & OR* \\
\hline $\begin{array}{l}\text { Non-salaried } \\
\text { long-term } \\
\text { employment }\end{array}$ & 16.2 & ns** & 24.8 & ns $^{* *}$ & 29.0 & 0.65 \\
\hline $\begin{array}{l}\text { Salaried } \\
\text { long-term } \\
\text { employment }\end{array}$ & 13.1 & 1 & 21.4 & 1 & 28.8 & 1 \\
\hline $\begin{array}{l}\text { Salaried } \\
\text { short-term } \\
\text { employment }\end{array}$ & 30.3 & 4.2 & 40.9 & 4.1 & 46.0 & 3.7 \\
\hline
\end{tabular}

* OR: Odds ratios (significant at the 5 percent threshold) from logistical regressions determining the probability of leaving active employment as a function of the age at the onset of an illness, of gender, type of illness and employment status the year preceding the onset of the illness.

** ns: OR not significant at the 5 percent threshold.

Reading note: For a non-salaried person in long-term employment at $\mathrm{n}-1$, the probability of not being in active employment at $\mathrm{n}+2$ for an illness which started at the year $n$ is 35 per cent less than it is for a salaried worker in long-term employment.

Population: All health problems having affected persons in longterm employment, whether salaried or non-salaried, and in short-term employment the preceding year $(\mathrm{n}=9123)$.

Source: SIP 2006 (Drees-Dares).

\section{Modulating Professional Activity}

In this second form of the impact of an illness, we no longer observe a rupture or reorientation in career, but a modulation whose framework is very much determined by the insurance systems (whether or not there are interruptions of activity in relation to temporary work leave) and by the nature of the activity (adaptations of the temporal dimensions whose shared characteristics were discussed in the first part). 


\section{Interruption of Activity}

The comparison of salaried employees and nonsalaried workers reveals radically different behaviour patterns concerning temporary work leave which echoes what was earlier observed in the utilisation of health care. The probability for non-salaried workers stopping work when illness strikes ${ }^{(40)}$ is two-thirds less than for that of employees in long-term employment, whether the work leave is singular or repetitive (see Table 7). Non-salaried workers seem to maintain their work activity much more than do salaried employees, but their respective rights in this area are so different that the comparability of their behaviour cannot be guaranteed.

Table 7: Consequences of an Illness in Terms of Work Stoppages and Changes in Professional Career

\begin{tabular}{|l|c|c|c|c|}
\cline { 2 - 5 } \multicolumn{1}{c|}{} & \multicolumn{3}{c|}{ Consequences of an illness } \\
\hline \multirow{2}{*}{ Situation one year earlier } & \multicolumn{2}{|c|}{$\begin{array}{c}\text { One or } \\
\text { more work } \\
\text { stoppages* }\end{array}$} & \multicolumn{2}{|c|}{$\begin{array}{c}\text { On } \\
\text { professional } \\
\text { career* }\end{array}$} \\
\cline { 2 - 5 } & In \% & OR $1^{* *}$ & In \% & OR2*** \\
\hline $\begin{array}{l}\text { Long-term non-salaried } \\
\text { employment }\end{array}$ & 29.4 & 0.33 & 35.8 & ns \\
\hline $\begin{array}{l}\text { Long-term salaried } \\
\text { employment }\end{array}$ & 52.9 & 1 & 34.0 & 1 \\
\hline Short-term employment & 47.2 & 0.66 & 41.9 & 1.4 \\
\hline
\end{tabular}

* Using two questions from the SIP survey a propos three or more illnesses left to the choice of the person interviewed among those which "seemed the most linked to his/her professional life whether as a cause or a consequence."

** OR 1: Odds ratio from a logistical regression on the probability of having one or more work stoppages linked to an illness as a function of the age at the onset of the illness, gender, the type of illness and the employment status.

*** OR2: Same thing but a propos the probability of declaring that an illness had consequences on one's professional career.

Reading note: For a non-salaried person in long-term employment the year preceding the illness, the probability of taking one or more sick leaves linked to the illness is two thirds less than that for a salaried person in long-term employment.

Population: All illnesses affecting persons in long-term employment, whether salaried or non-salaried, or in short-term employment the year preceding the illness.

Source: SIP 2006 (Drees-Dares)

Just as in the case of the utilisation of health care, sick leave is highly dependent on legal provisions. This temporary interruption for salaried employees has been regulated by law for a long time ${ }^{(41)}$ suspending their work contract and complementing their temporary loss of income with per diem indemnities funded by active employees and by the employers. The situation of non-salaried workers is quite different and is less advantageous, as we have pointed out, despite the restrictions recently

(40) This only involves those illnesses that the respondents judged as having marked their lives the most, according to the $S I P$ survey interrogation method, that is some 83 per cent of all the cases of illness recorded in the survey.

(41) Sylvie Bourgeot and Michel Blatman (2009, p. 288) trace the origins of this rule to a 1934 jurisprudence (Chambre civile, 3 December, Hôtel Terminus, PLM c/dame Spagnoli). imposed on the general system. ${ }^{(42)}$ Only selfemployed crafts workers and merchants are subject to a social tax and entitled to protection against the risk of interruption of work activity, receiving daily indemnities although they are less favourable in both duration and value than those accorded to salaried employees. The self-employed professionals are individually insured, but without any obligation to do so, and under varying conditions of the proposed coverage and contribution levels. The situation is similar for farmers, ${ }^{(43)}$ except for illnesses or accidents of recognized occupational origin and for which they receive daily indemnities.

Moreover, the risks associated with a temporary suspension of activity of salaried employees and non-salaried workers have little to do with each other. Employees are mainly threatened with dismissal and, while the risk is not zero, the law of 12 July $1990^{(44)}$ stating that illness cannot in and of itself be a cause for termination of employment ensures their greater security in this respect. The risks for the self-employed are quite different. The loss of income is not compensated, we have seen, and the inability to maintaining their activity is certainly a threat through the weakening of the network of relationships formed, in particular with clients. It is likely that interrupting work activity is only a solution of last resort for the self-employed.

The possibility of temporarily suspending professional activity is sensitive to employment status insofar as the rights associated with an interruption make it more or less effective and more or less dangerous to the future evolution of a career. Sick leave by salaried employees and non-salaried workers are very different and difficult to compare. To those who establish a firm or even a virtuous link between job retention and a weaker, and thus economically incentive, social protection, one might object by pointing out the cost which maintaining work activity engenders for the individual and the community in terms of delays in health care and ultimately the possibility of worsening health. Here again we find the question which was raised earlier of the self-employed significantly underutilizing consultations of medical specialists and especially of general practitioners over a twelve-month period. For the time being, the SIP survey does not inform us of these aspects which, however, should remain present in interpreting the results.

(42) The decree of 26 December 2011, for example, has installed a method of calculating per diem indemnities which is less favourable to those who are insured by the general insurance plan $\left(J O R F \mathrm{n}^{\circ} 0299,27\right.$ December 2011, p. 22,309). This had been preceded by two previous decrees of 29 October 2010 which had already lowered the calculation of cash indemnities. And look at article 105 of the financial law of $2012\left(\mathrm{n}^{\circ} 2011\right.$ 1977 of 28 December 2011) which installed an unpaid sick leave day in the civil service.

(43) Negotiations are underway to set up per diem indemnities for illnesses other than those recognized as being work-related. (44) Which has become article L. 1132-1 of the Labour Code. 


\section{Modulating Working Time}

The second adaptation considered here concerns working time whose specificities for the selfemployed we have seen and which we have translated in terms of "influence over daily life." We wanted to know how these specific characteristics are reflected in the context of an illness so as to know if they were additional constraints due to the number of hours worked and the influence of work over daily life, or if they were resources for the self-employed. Illness and the consequent medical treatment are indeed likely to generate tensions in the temporal organization of self-employed activities and we therefore wanted to identify the necessary adjustments. In undertaking this analysis, we distinguished 211 people who reported at least one chronic illness among the 879 non-salaried workers interviewed in SIP and we did the same for salaried managerial personnel and for other employees. Table 8 presents the results of some key dimensions of working time for each group considered by separating the statements of people who reported having a chronic disease (column Chronic Disease) from the others. The limited numbers call for considerable caution in the interpretation. Despite these reservations, we present the results for some of the interesting reported differences, taking them as so many lines to be adopted in future studies so as to either confirm or reformulate them. So Table 8 is here used to formulate very tentative hypotheses.

Table 8: Chronic Diseases Among the Actively Employed and Work Conditions

\begin{tabular}{|c|c|c|c|c|c|c|}
\hline & \multicolumn{2}{|c|}{$\begin{array}{l}\text { Non- } \\
\text { salaried }\end{array}$} & \multicolumn{2}{|c|}{$\begin{array}{c}\text { Mana- } \\
\text { gerial, } \\
\text { professio- } \\
\text { nal }\end{array}$} & \multicolumn{2}{|c|}{$\begin{array}{c}\text { Other } \\
\text { salaried }\end{array}$} \\
\hline & \multicolumn{6}{|c|}{ Chronic disease } \\
\hline & Yes & No & Yes & No & Yes & No \\
\hline Population & 211 & 668 & 252 & 762 & 1681 & 4539 \\
\hline $\begin{array}{l}\text { Number of hours } \\
\text { worked during the } \\
\text { last week worked } \\
\end{array}$ & 47.9 & 49.4 & 41.0 & 41.6 & 35.1 & 36.3 \\
\hline $\begin{array}{l}\text { Night-work (always } \\
\text { or often) }\end{array}$ & $4 \%$ & $8 \%$ & $2 \%$ & $3 \%$ & $9 \%$ & $9 \%$ \\
\hline $\begin{array}{l}\text { Work week more } \\
\text { than } 48 \text { hours (always } \\
\text { or often) }\end{array}$ & $60 \%$ & $58 \%$ & $29 \%$ & $29 \%$ & $9 \%$ & $8 \%$ \\
\hline $\begin{array}{l}\text { Irregular and } \\
\text { unpredictable hours } \\
\text { (always or often) }\end{array}$ & $28 \%$ & $31 \%$ & $16 \%$ & $18 \%$ & $10 \%$ & $12 \%$ \\
\hline $\begin{array}{l}\text { Physically demanding } \\
\text { work }\end{array}$ & $52 \%$ & $49 \%$ & $17 \%$ & $14 \%$ & $40 \%$ & $32 \%$ \\
\hline Work under pressure & $29 \%$ & $30 \%$ & $53 \%$ & $43 \%$ & $29 \%$ & $23 \%$ \\
\hline
\end{tabular}

Reading note: Non-salaried workers declaring at least one chronic illness work 47.9 hours per week on the average. Those who declared no illness worked 49.4 hours. Some 52 per cent of the former feel that their work is physically demanding as compared to 49 per cent of the latter.

Population: Active employed 15 years and over.

Source: SIP 2006 (Drees-Dares).
The data in Table 8 already clearly confirm the impact of illness regardless of the employment status considered. Those who are ill always consider their work as "physically demanding" (line 5), more so than for those who are healthy and have the same employment status. This result is generally understood as the result of two mechanisms: health problems make them more susceptible to the difficulties of work and these in turn contribute to health deterioration. ${ }^{(45)}$ Note, however, that the self-employed more often report encountering such physical demands than do other categories of employed persons (whether or not they have declared a chronic illness).

Whether sick or not, non-salaried workers always reported the highest weekly working hours (lines 1 and 3). They also practice irregular hours less often when they are ill rather than healthy, but this is also the case for salaried managerial personnel and other employees. However, the gap concerning night work (line 2) between those who are ill and those who are healthy among the self-employed seems to be more sensitive than it is for other employment statuses. There are only half as many self-employed who are ill but who always or often work at night, than is the case for those who are not ill. When these results are controlled by the variables of age, gender and industry, they are, however, no longer significant. Employment status "does not explain" the differences in night work for those self-employed that are ill compared to those who are not.

Nevertheless, it seems useful to keep these results within the framework of the exploratory approach which we have presented here and to which we have referred above, the objective of which is to form tentative hypotheses to guide future research. Even from this limited point of view, the data in Table 8 suggest that maintaining a high number of hours worked by non-salaried workers when they are ill may be accompanied by an adjustment in the degree to which they are exposed to atypical hours (in proportions equivalent to those of salaried employees) and to night work. We may have here an obvious effect of the autonomy of work organization that the self-employed typically present as a feature of their activity and is sometimes considered the major difference with respect to salaried employees. However, in an analysis with all the rest being equal, the employment status variable is not significantly correlated to adjustments of working time in case of illness. In other words, the consequences of illness

(45) This leads to better understanding of the choice of French statistical surveys on work conditions which develop individual's subjective appreciation about "objectivable" work conditions. Swedish studies, for example, have taken a completely different road by describing work conditions uniquely from objective measures: weight lifted, temperature, decibels, etc. See Gollac, Volkoff (2010). And concerning the endogenous character of the declarations on work conditions, see Coutrot, WolfF (2005). 
reveal an interesting test of this supposed autonomy. By examining the different forms of adjustment of working time, we might understand their reality and their scope or, on the contrary, question them.

Non-salaried workers seem less exposed to "working under pressure" than are salaried managerial personnel (line 6, Table 8), a characteristic generally correlated with psychosocial risks. In addition, salaried managerial personnel and other employees report "working under pressure" significantly more often when they are ill than when they are in good health $(53 \%$ vs. $43 \%$ and $29 \%$ vs. $23 \%$ respectively for these two groups of salaried employees report working under pressure when they are ill vs. when they are healthy). In contrast, the self-employed who are ill declare working under pressure just as often as their colleagues in good health. At least, we can conclude that the feeling of working under pressure does not gain ground among the self-employed despite illness, while for all other employees this degradation is significant. This may be a sign that opportunities for organization and management of work during illness -less accessible to employees in such cases- are mobilized by the self-employed to modulate the pressure felt at work.

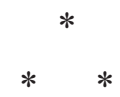

Our analyses confirm that the self-employed report better health than employees and we describe this relative advantage. The self-employed report having better health than do salaried non-managerial employees, but they generally have worse health than that of managerial employees, who retain their advantages in this case. In this intermediate position, the self-employed are also close to the declarations of the intermediate professional employees. For some health variables, this relative health advantage is widely shared among subgroups in the self-employed status. This is true of reports of declarations of symptoms and the use of general practitioners which is always less frequent than for employees, regardless of the latter's PCS. For other variables, the differences related to employment status are less clear and the classic influence of PCS on health reasserts itself, with salaried managerial personnel returning to their more favourable position.

The health benefit of the self-employed, while it is well proven, is not, however, perfectly homogeneous for all subgroups within the employment status. But an interesting point of our analysis is that the differences are not found along a classic employees' health gradient. Specifically, the selfemployed professionals do not enjoy the benefits that higher educational qualifications and income imply with respect to individual farmers, selfemployed crafts workers and merchants. From the point of view of health, they do not embody the equivalent of the "managerial personnel" of the self-employed. Even if they say they are in good health more often than any other group, the number of their illnesses or their declarations concerning stress lead to qualifying this picture. Only in the utilisation of medical specialists are they positively distinguished from other subgroups among the self-employed.

Thus, taking into account the employment status changes or displaces the results obtained from the PCS which are no longer so universally operative. Having said that, we do not posit a direct and unambiguous causal link between employment status and health. Instead, we suggest that the employment status, specifically that of non-salaried workers, contains dimensions whose effects are evident in health statements and in health care behaviour. Thus there is the reduced use of general practitioners or of sick leave, these two examples showing how the alternatives open to the worker change depending on their rights, and therefore -in a country like France, structured by Bismarckian principles ${ }^{(46)}$ according to their employment status. Finally, we can ask whether the rights associated with employment status affect the very way health declarations are made, e. g. the higher likelihood of reporting symptoms of stress, rather favourable perceptions of health status, and significantly greater job satisfaction than for other professional groups. Several recent studies have reported such specific statements about other aspects of self-employment (Riesco, 2012; Burri, 2011; Bessière, Gollac, 2007; Gollac, 2005; CÉlÉrIER, 2002). Health could be another singularity whose understanding will make a useful contribution to the wider debate on how health is experienced and expressed.
(46) Belgium, the Netherlands, Germany and Austria also structure their health rights on these same principles, traditionally distinguished from "Beveridgian" principles which are universally -rather than professionally-based and are financed through taxes. The Scandinavian countries, Ireland, and the United Kingdom apply this second option. 


\section{Bibliography}

Algava E., Cavalin C., Célérier S. (2011), «La santé des indépendants: un avantage relatif à interpréter», Document de travail, $\mathrm{n}^{\circ} 150$, Noisy-le-Grand, Centre d'études de l'emploi.

Algava E., VincK L. (2009), «Les conditions de travail des non-salariés en $2005 »$, Premières Synthèses, $\mathrm{n}^{\circ} 50.1$.

Amossé T., Daubas-Letourneux V., Le Roy F., Meslin K., Barragan K. (2012), «Les accidents du travail et problèmes de santé liés au travail dans l'enquête SIP. (In)visibilités et inscriptions dans les trajectoires professionnelles », Rapport de recherche, $\mathrm{n}^{\circ} 76$, Noisy-le Grand, Centre d'études de l'emploi.

Bessière C., De Paoli C., Gouraud B., Roger M. (2011), «Les agriculteurs et leur patrimoine : des indépendants comme les autres? », Économie et statistique, $\mathrm{n}^{\circ} 444-445$, pp. 55-74.

Bessière C., Gollac S. (2007), «Le silence des pratiques. La question des rapports de genre dans les familles d'“indépendants"», Sociétés \& représentations, vol. 24, $\mathrm{n}^{\circ} 2$, pp. 43-58.

BEH (2011), «Inégalités sociales de santé», Bulletin d'épidémiologie hebdomadaire, $\mathrm{n}^{\circ}$ 8-9, pp. 73-100.

Bourgeot S., Blatman M., (2009), L'état de santé du salarié, Paris, Éditions Liaisons.

BURRI S. (2011), «La conciliation de la vie professionnelle, privée et familiale», in Milewski F., Périvier H., Les discriminations entre les femmes et les hommes, Paris, Presses de Sciences Po, pp. 253-280.

Cambois E., Laborde C., Robine J.-M. (2008), «La “double peine" des ouvriers : plus d'années d'incapacité au sein d'une vie plus courte», Population et sociétés, $\mathrm{n}^{\circ} 441$.

Cavalin C., Célérier S. (2012a), «Une mesure de la santé à l'âge du travail. Approche du travail par la santé à partir de l'enquête Événements de vie et santé (EVS, Drees, 2005-2006) ", Rapport de recherche, $\mathrm{n}^{\circ}$ 78, Noisy-leGrand, Centre d'études de l'emploi.

Cavalin C., Célérier S. (2012b), «Mesurer les dimensions mentales de la santé au travail. Sous quels angles? », in Stroobants M. (ed.), Mesure et démesures du travail, Bruxelles, l'Université Libre de Bruxelles, pp. 185-195.

CÉLÉRIER S. (2008), « Cancer et activités professionnelles : les enseignements de 30 ans de littérature internationale sur le thème», Santé et sociologie, n 38, pp. 201-216.

CÉLÉRIER S. (2002), “"Micro-entreprises”: entre contraintes et expression de soi», in Insee Méthode, $\mathrm{n}^{\circ} 99$, pp. 123-134.

Chassaing K., Lasne N., Le Clainche C., Waser A.-M. (2011), «Travailler avec un cancer. Regards croisés sur les dispositifs d'aménagement des conditions de travail et sur les ressources mobilisées pour tenir ensemble travail et santé», Rapport de recherche, $\mathrm{n}^{\circ} 63$, Noisy-leGrand, Centre d'études de l'emploi.

Chauvel L. (2001), "Le retour des classes sociales? », Revue de l'OFCE, $\mathrm{n}^{\circ}$ 79, pp. 315-359.

Chenu A. (2002), «Les horaires et l'organisation du temps de travail», Économie et statistique, n 352-353, pp. 151-167.

Coutrot T., WolfF L. (2005), «L'impact des conditions de travail sur la santé : une expérience méthodologique», Rapport de recherche, $\mathrm{n}^{\circ} 23$, Noisy-le-Grand, Centre d'études de l'emploi.

DeSalvo K. B., Fan V. S., McDonnell M. B., Finh S. D. (2005), "Predicting mortality and healthcare utilization with a single question", Health services research, vol. 40, $\mathrm{n}^{\circ} 4$, pp. 1234-1246.

Domens J., Pignier J. (2012), «Auto-entrepreneurs : au bout de trois ans, 90\% dégagent un revenu inférieur au Smic au titre de leur activité non salariée», Insee première, $\mathrm{n}^{\circ} 1414$.

Eichenbaum-Voline S., Malavolti L., Paraponaris A., Ventelou B. (2008), «Cancer et activité professionnelle», Revue de l'OFCE, vol. 104, n 1, pp. 105-134.

Erdogan-Ciftci E., Van Doorslaer E., Bago d’Uva T., VAN Lenthe F. (2010), "Do self-perceived health changes predict longevity?", Social science \& medicine, vol. 71, $\mathrm{n}^{\circ} 11$, pp. 1981-1988.

Evain F., Amar M. (2006), «Les indépendants», Insee première, $\mathrm{n}^{\circ} 1084$.

Gollac M., Volkoff S. (2000), Les conditions de travail, Paris, La Découverte, coll. «Repères ».

Gollac M., Volkoff S. (2010), «Mesurer le travail. Une contribution à l'histoire des enquêtes françaises dans ce domaine», Document de travail, $\mathrm{n}^{\circ} 127$, Noisy-le-Grand, Centre d'études de l'emploi.

Gollac S. (2005), «Faire ses partages», Terrain, $\mathrm{n}^{\circ}$ 45, pp. 113-124.

Ha-Vinh P., Regnard P., Sauze L. (2010), « Arrêts de travail pour cancer dans une population de travailleurs indépendants ", Documents pour le médecin du travail, $\mathrm{n}^{\circ} 124, \mathrm{pp} .413-422$.

Ha-Vinh P., RÉGnARd P., SAuZe L. (2011), « Consommation de médicaments psychotropes par les travailleurs indépendants français en activité », La presse médicale, vol. $40, \mathrm{n}^{\circ} 4$, part. 1 , pp. e173-e180.

InSEe (2009), Les revenus d'activité des indépendants, coll. «Insee Références».

InSERM (2011), Stress au travail et santé. Situation chez les indépendants, Paris, Inserm.

Jusot F., Khlat M., Sermet C. (2006), «Une mauvaise santé augmente fortement les risques de perte d'emploi», 
in Données sociales. La société française, Paris, Insee, pp. 533-542.

Khlat M., Sermet C. (2004), «La santé des chômeurs en France : revue de littérature», Revue d'épidémiologie et de santé publique, vol. 52, $\mathrm{n}^{\circ}$ 5, pp. 466-474.

Levratto N., Serverin É. (2009), «Être entrepreneur de soi-même après la loi du 4 août 2008 : les impasses d'un modèle productif individuel», Revue internationale de droit économique, t. XXIII, $\mathrm{n}^{\circ} 3$, pp. 325-352.

Malenfant R., Larue A., Jetté M., Vézina M., St-Arnaud L. (2004), Précarisation du travail et santé : briser le cercle vicieux de l'exclusion, Ripost, CLSC Haute-Ville-Des-Rivières.

Maurin M.-L., Dupuy Y., Larré F., Sublet S. (éd.) (1999), «Prestation de travail et activité de service», Cahier travail et emploi, $\mathrm{n}^{\circ} 1999$.

Mesrine A. (2000), «La surmortalité des chômeurs : un effet catalyseur du chômage? ", Économie et statistique, $n^{\circ} 334$, pp. 33-48.

Millunpalo S., Oja P., Pasanin M., Urponen H. (1997), "Self-rated health status as a health measure. The predictive value of self-reported health status on use of physician services and on mortality in the working age population", Journal of Clinical Epidemiology, vol. 50, $\mathrm{n}^{\circ} 5$, pp. 517-528.

Missègue N. (2000), «Le temps de travail des indépendants », Insee première, $\mathrm{n}^{\circ} 695$.

Perronnin M., Pierre A., Rochereau T. (2011), «La complémentaire santé en France en 2008: une large diffusion, mais des inégalités d'accès», Questions d'économie de la santé, $\mathrm{n}^{\circ} 161$.

Ricroch L., Roumier B. (2011), «Depuis 11 ans, moins de tâches ménagères, plus d'Internet», Insee première, $\mathrm{n}^{\circ} 1377$.

Riesco A. (2012), «Le travail indépendant des immigrés et sa sociologie», in Desmarez P., Lanciano-Morandat C., Monchatre S. et al., Temps, travail et salariat : Mateo Alaluf et Pierre Rolle, actualité de leur pensée, Toulouse, Octarès, pp. 57-66.

Rolle P. (1988), Bilan de la sociologie du travail, Tome 1, Grenoble, Presses universitaire de Grenoble.

Saurel-Cubizolles M.-J. (2001), «État de santé perçu et perte d'emploi», in Travail, santé, vieillissement, relations et évolutions : colloque des 18 et 19 novembre 1999, Toulouse, Octarès.

Spelten E. R., Sprangers M. A., Verbeek J. H. (2002), "Factors reported to influence the return to work of cancer survivors: a literature review", Psycho-Oncology, vol. $11, \mathrm{n}^{\circ} 2$, pp. 124-131

Supiot A. (2009), Le droit du travail, Paris, Presses universitaires de France, coll. «Que sais-je? », 4e éd. mise à jour.

TAButEau D. (2010), «La métamorphose silencieuse des assurances maladie», Droit social, n ${ }^{\circ}$, pp. 85-92.

Tubeuf S. (2010), «Mesure des inégalités de santé : la méthode "Ecuity" appliquée à la France», La Lettre $d u$ Collège des économistes de la santé, vol. $21, \mathrm{n}^{\circ} 1$, pp. 5-6. 